Article

\title{
Heat and Mass Transfer, and Volume Variations in Banana Slices during Convective Hot Air Drying: An Experimental Analysis
}

\author{
Raimundo P. Farias ${ }^{1}$, Ricardo S. Gomez ${ }^{2, *}$, Wilton P. Silva ${ }^{3}{ }^{\mathbb{D}}$, Leonardo P. L. Silva ${ }^{4}$, \\ Guilherme L. Oliveira Neto ${ }^{5}$, Ivonete B. Santos ${ }^{6}$, João E. F. Carmo ${ }^{2}$, José J. S. Nascimento ${ }^{7}$ \\ and Antonio G. B. Lima ${ }^{2}$ \\ 1 Department of Agricultural Sciences, State University of Paraiba, Catolé do Rocha, PB 58884-000, Brazil; \\ rp.eng.tec@gmail.com \\ 2 Department of Mechanical Engineering, Federal University of Campina Grande, Campina Grande, \\ PB 58429-900, Brazil; jevan.franco@gmail.com (J.E.F.C.); antonio.gilson@ufcg.edu.br (A.G.B.L.) \\ 3 Department of Physics, Federal University of Campina Grande, Campina Grande, PB 58429-900, Brazil; \\ wiltonps@uol.com.br \\ 4 Federal Institute of Education, Science and Technology of Paraíba, Cajazeiras, PB 58900-000, Brazil; \\ lpdelsilva@gmail.com \\ 5 Federal Institute of Education, Science and Technology of Piauí, Floriano, PI 64800-000, Brazil; \\ guilherme@ifpi.edu.br \\ 6 Department of Physics, State University of Paraiba, Campina Grande, PB 58429-500, Brazil; \\ ivoneetebs@gmail.com \\ 7 Department of Materials Engineering, Federal University of Campina Grande, Campina Grande, \\ PB 58429-900, Brazil; jeffpesquisador@gmail.com \\ * Correspondence: ricardosoaresgomez@gmail.com; Tel.: +55-83-98893-7991
}

Received: 3 August 2020; Accepted: 21 September 2020; Published: 23 September 2020

\begin{abstract}
Bananas are some of the most consumed fruits throughout the world, providing metabolizable calories and vitamins for humans, along with many other benefits. However, this fruit tends to be easily degraded by microorganisms and other chemical agents because of the high moisture content. Considering the importance, this work focuses on an experimental study regarding banana fruit drying. For such purpose, whole bananas were hand-peeled and sliced longitudinally and then dried by a hot air circulation oven with air temperatures of $40{ }^{\circ} \mathrm{C}, 50{ }^{\circ} \mathrm{C}, 60{ }^{\circ} \mathrm{C}$ and $70^{\circ} \mathrm{C}$. Measurements of mass, temperature, and dimensions of the sample were done during the drying process. Results of drying, heating, and shrinkage (volume and surface area) kinetics are presented and analyzed. The study revealed that the drying air temperature significantly affected moisture removal, heating, and dimensions' variation rates, as well as quality of banana fruit. The drying carried out with higher temperature and lower relative humidity of the air gave rise to higher rates of drying, heating and variation of dimensions, and shorter drying time of the product.
\end{abstract}

Keywords: heat; mass; shrinkage; banana; experimental

\section{Introduction}

Fruits are capable of providing flavor and diversities to the human diet, and are important and indispensable sources of vitamins, minerals, fiber, and carbohydrates. Because of that nutritional characteristics, and coupled with population growth, the production and consumption of processed fruits are progressively increasing. Bananas are an important source of human food mainly due to their mineral and vitamin contents and also the provided calorific value (energy). Furthermore, it contains 
dopamine and various phenolic compounds, for example, catechin in its composition without the intakes of fats and cholesterol [1]. Due to nutritional and aromatic characteristics, bananas have received considerable attention from researchers, which identified more than 350 compounds present in the fruit. The major constituents are the amyl and isoamyl esters of butyric, propionic and acetic acids. Brazil occupies a prominent place in world banana production. However, the losses of this product are estimated to be up to $60 \%$ of the total volume of production [2-4]. Despite being harvested in quantities and qualities due to the practically equal seasonal season throughout the year, the fruit must be consumed within a maximum period of up to 25 days after harvest.

Bananas are highly hygroscopic biological products, i.e., they contain a lot of bound water and shrink during drying. Hygroscopic products have the property of exchanging water, in the form of vapor or liquid, distributed in the external environment past over it, through absorption or desorption, considering the water characteristics of the products and the environment that surrounds them. Other than $19 \%$ of sugars and $1 \%$ starch content, the fruit is composed of water $(60-80 \%$ depending on the degree of ripeness and fruit variety and type); protein; carbohydrate, with regular content of calcium, iron, copper, zinc, iodine, manganese and cobalt, fiber, beta-carotene, thiamine, riboflavin, niacin, and vitamin $C[1,5-8]$. They are highly perishable fruits and susceptible to the creation of microorganisms that leads to their deterioration in less time; thus, some actions must be taken into considerations to increase shelf-life and product quality.

Fruit drying is still considered a complex operation deserving better/progressive understanding, especially with regard to the selection and control of the process conditions to maintain the final quality of the product. The demand of consumers has increased and products that preserve their original characteristics to the maximum have gained the consumer's preference. At the industrial level, this means the development of operations that minimize the adverse effects of the drying process. During drying, the product's surface shrinks more than its core, causing internal stresses that result in damage and rupture of the walls inside the product. Allied to this, non-volatile compounds also migrate with the diffused water and precipitate on the surface of the product, forming a crust that maintains the dimensions of the product [9]. Thus, shrinkage affects the parameters of heat and mass transfer and is a relevant factor to be taken into account in drying models. According to previously published literature $[9,10]$, initially, the shrinkage occurs on the surface, and then gradually moves to the center of the fruit with an increase in the drying time. Then, the shrinkage produces a variation in the distance required for the movement of water molecules, which facilitates the diffusion of moisture across the surface and, at the same time, the size of the pore filled with water shrinks due to water loss. When the pore shrinks in volume, it becomes more difficult for moisture to move from the core to the surface of the fruit. Then, the diffusion coefficient decreases with the shrinkage of the sample structure and tissue.

From a technological and commercial point of view, due to the wide variety of vitamins and nutrients, bananas have been intensely consumed "fresh" and like industrial products. The processing of bananas to obtain elaborated products has been directed to green banana flour, green and ripe banana flour or powder, creams, flakes, raisins, puree, nectar, jelly, bananas, brown sugar, mints, vinegar, wine, and bananas-raisin, liqueur, juice, cake, pie and banana to rum. Fiber is also obtained for the manufacturing of bags for cereals, heart of palm brine, banana peel pie, and stalk pie. This fiber is extracted from the plant, from the remains of the bunches, and from the bananas themselves. The remains of bananas and bunches have also been used in animal feed [1,11-15].

The dried banana, or raisin banana, is obtained from the artificial drying of the ripe banana using different techniques such as solar drying, freeze-drying (lyophilization), in an oven and with a heated cylinder, with and without treatment. It is usually obtained from dwarf banana or "nanicão" type. It is a small-scale industrialized product; however, numerical data on the volume of national sales were not found in the literature. The product obtained is of very dark color, firm consistency, and little persistent banana flavor. Dried banana products can be stored satisfactorily for more than a few years without the addition of preservatives. It is assumed to be due to the high sugar content, 
which exceeds $50 \%$. The use of suitable drying techniques can lead to a product with a light color, soft consistency, and pleasant taste and aroma. Banana is a non-porous solid, whose moisture is linked to the structure and, during drying of this food, the period of constant drying rate is not noticed [11,13]. Dried bananas are stable to the action of microorganisms if the moisture content is less than $23 \%$ $\left(\mathrm{MC}_{\mathrm{w} . b .}\right)$. Industrially, drying is carried out until the banana's moisture reaches about $20-25 \%\left(\mathrm{MC}_{\mathrm{w} . b .}\right)$ and water activity less than 0.7 at $25^{\circ} \mathrm{C}$, and its control is carried out in a practical way, by observing the color, texture, consistency, chew, and water content of the final product. In general, to produce a product of acceptable quality, bananas must be dried to a moisture content of $14 \%$ to $15 \%\left(\mathrm{MC}_{\mathrm{w} . b .}\right)$, using a maximum temperature of $70{ }^{\circ} \mathrm{C}$.

Temperature and drying time are important parameters to alter the color changes of agricultural products during drying, especially fruits. Thus, different factors related to drying of banana have been cited in previous literature [3,4,16-25]. Specifically, previous studies also extensively correlated the phenomena of color and texture changes in bananas during drying [26-32]. Due to the sequential growth of the banana crop and the amount of banana harvested, the increased losses of these fruits, for the reasons already mentioned in this text, and the minimization of energy consumption in the process, there is a need for more and more effective studies and optimized related to banana conservation. In this sense, the authors, concerned with the high rates of lost banana, mainly in the post-harvest phase, propose to study the drying of bananas in ovens under different operational conditions.

\section{Materials and Methods}

Bananas (Musa species and "silver" variety) were obtained from the local market in the city of Campina Grande, Paraiba state, Brazil.

In the beginning, bananas were selected with respect to size, quality, and qualitative degree of ripeness (yellow peel with minimal black spot), hand-peeled, and longitudinally sliced in half, before the start of each experiment. Then, the dimensions, mass, and surface temperature of each sample were measured, as well as the temperature and relative humidity of the ambient air.

The samples were placed inside the oven and dried at different temperatures $\left(40^{\circ} \mathrm{C}, 50^{\circ} \mathrm{C}, 60^{\circ} \mathrm{C}\right.$, and $70^{\circ} \mathrm{C}$ ). The samples were arranged inside the oven as follows: a pilot sample placed on a small thin wire mesh and 6 samples on a large thin wire mesh at identical locations for each experimental run as shown in Figure 1a.

In predefined time intervals (a 5 min increment from 0-30 min; $10 \mathrm{~min}$ from 31-60 $\mathrm{min}$; $30 \mathrm{~min}$ from $61-120 \mathrm{~min}$; $60 \mathrm{~min}$ from 121 till the end of the process), the samples were taken in the interior of the oven, in order to measure the temperature, mass, and dimensions.

At the end of each drying period ( $5 \mathrm{~min}, 10 \mathrm{~min}, 30 \mathrm{~min}$ and $60 \mathrm{~min}$ intervals) measurements of mass, temperature and dimensions were made only in the pilot sample and, at the end of each drying step (first $30 \mathrm{~min}$, second $30 \mathrm{~min}$, second hour and third hour until to final drying), measurements of temperature, mass, and dimensions were made in all samples.

When the mass of the pilot samples reached the moisture level close to the hygroscopic equilibrium condition (three consecutive values approximately equals), the measurements were terminated and then the samples were kept inside the oven under the same drying conditions for a period of $24 \mathrm{~h}$ to obtain the mass of balance (hygroscopic equilibrium condition). Then, the temperature inside the oven was changed to $70^{\circ} \mathrm{C}$, and the samples were kept inside the oven for another period of $24 \mathrm{~h}$ to obtain the dry product mass.

Figure 1 illustrates the banana cut into longitudinal slices and a diagram indicating the dimensions' half perimeter (C), length of the major axis (L), and diameter (D), and the position where temperature on the banana surface were obtained in each experiment. Tables 1 and 2 show the experimental information about the fruit and drying air. 

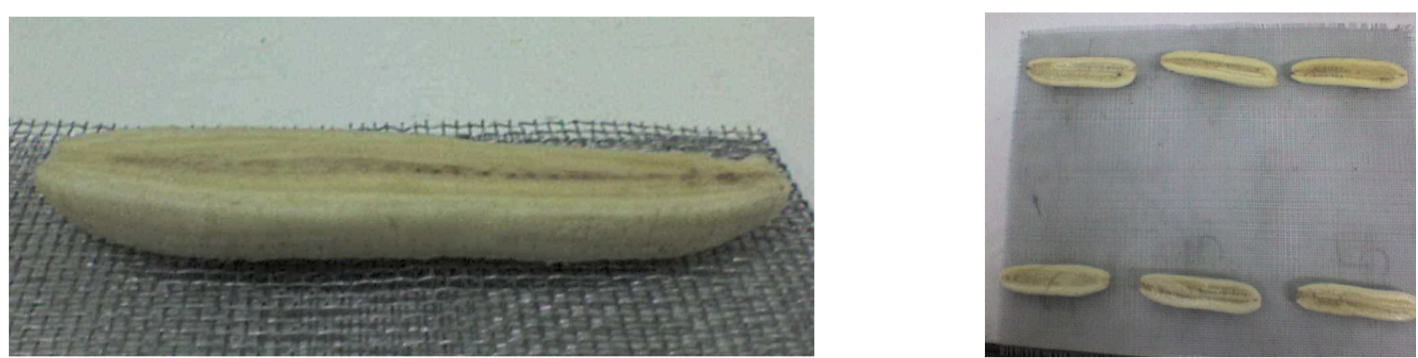

(a)

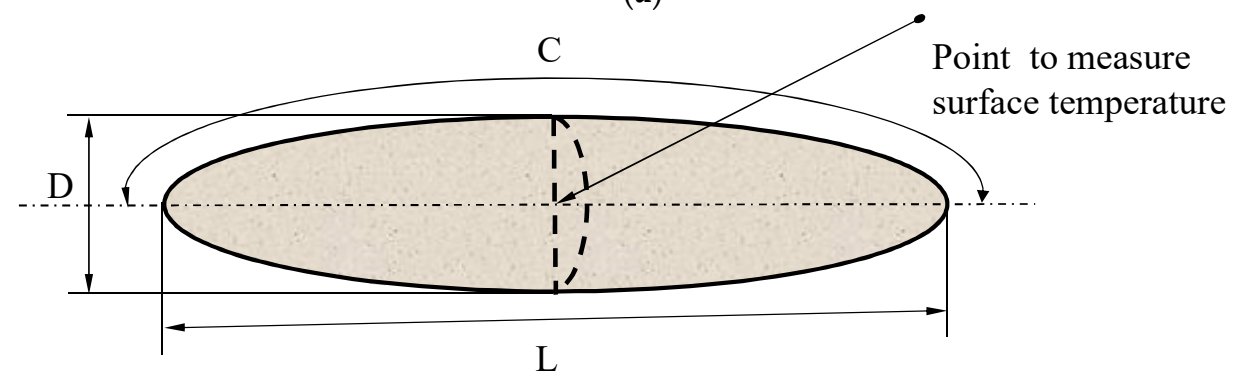

(b)

Figure 1. (a) Banana sliced lengthwise positioned over a small thin wire mesh (left side) and large thin wire mesh (right side) and (b) identification of the point for thermal measurement and geometrical parameters of the fruit.

Table 1. Experimental geometrical parameters of the banana (longitudinal slices) and drying-air conditions used in this work.

\begin{tabular}{|c|c|c|c|c|c|}
\hline \multicolumn{3}{|c|}{ Air } & \multicolumn{3}{|c|}{ Banana (Longitudinal Slices) } \\
\hline $\mathrm{T}\left({ }^{\circ} \mathrm{C}\right)$ & RH (\%) & $\mathbf{v}(\mathrm{m} / \mathrm{s})$ & $\mathrm{C}(\mathrm{mm})$ & $\mathrm{L}(\mathrm{mm})$ & $\mathrm{D}(\mathrm{mm})$ \\
\hline $40.0 \pm 0.5$ & $29.60 \pm 1.00$ & $0.04 \pm 0.01$ & $133.00 \pm 0.53$ & $119.04 \pm 0.48$ & $25.34 \pm 0.11$ \\
\hline $50.0 \pm 0.8$ & $19.10 \pm 1.20$ & $0.05 \pm 0.01$ & $106.00 \pm 0.42$ & $98.87 \pm 0.63$ & $23.43 \pm 0.23$ \\
\hline $60.0 \pm 1.1$ & $10.71 \pm 0.80$ & $0.06 \pm 0.02$ & $120.00 \pm 0.53$ & $117.96 \pm 0.47$ & $27.20 \pm 0.31$ \\
\hline $70.0 \pm 0.9$ & $7.30 \pm 0.90$ & $0.07 \pm 0.01$ & $112.00 \pm 0.49$ & $95.55 \pm 0.64$ & $21.62 \pm 0.17$ \\
\hline
\end{tabular}

T-temperature; RH—relative humidity; v-velocity; C-half perimeter; L-length of the major axis; D-diameter.

Table 2. Experimental hydric and thermal parameters of the banana (longitudinal slices) used in this work.

\begin{tabular}{|c|c|c|c|c|c|c|}
\hline \multirow{2}{*}{$\frac{\text { Air }}{\mathrm{T}\left({ }^{\circ} \mathrm{C}\right)}$} & \multicolumn{5}{|c|}{ Banana (Longitudinal Slices) } & \multirow{2}{*}{$t(\min$} \\
\hline & $M_{o}$ (d.b.) & $M_{f}$ (d.b.) & $M_{e}$ (d.b.) & $\theta_{\mathrm{o}}\left({ }^{\circ} \mathrm{C}\right)$ & $\theta_{\mathrm{f}}\left({ }^{\circ} \mathrm{C}\right)$ & \\
\hline $40.0 \pm 0.5$ & $2.2366 \pm 0.2314$ & $0.2256 \pm 0.0164$ & $0.0749 \pm 0.0022$ & $25.6 \pm 0.4$ & $40.0 \pm 0.6$ & 1365 \\
\hline $50.0 \pm 0.8$ & $2.6548 \pm 0.3122$ & $0.0656 \pm 0.0012$ & $0.0324 \pm 0.0031$ & $28.1 \pm 0.8$ & $50.0 \pm 0.5$ & 1365 \\
\hline $60.0 \pm 1.1$ & $2.1595 \pm 0.1763$ & $0.0722 \pm 0.0023$ & $0.0195 \pm 0.0027$ & $27.5 \pm 0.7$ & $58.9 \pm 0.6$ & 1025 \\
\hline $70.0 \pm 0.9$ & $2.3587 \pm 0.2126$ & $0.0079 \pm 0.0015$ & $0.0080 \pm 0.0004$ & $26.7 \pm 0.9$ & $68.6 \pm 0.8$ & 630 \\
\hline
\end{tabular}

The calculation of the amount of water in each banana $\left(\mathrm{m}_{\mathrm{a}}\right)$ and in each measurement time was done based on the value of the mass of the banana $(\mathrm{m})$ and the mass of the dried banana $\left(\mathrm{m}_{\mathrm{s}}\right)$, as follows:

$$
\mathrm{m}_{\mathrm{a}}=\mathrm{m}-\mathrm{m}_{\mathrm{s}}
$$

The calculation of the moisture content of each sample $(\mathrm{M})$ and at each measurement time was made based on the value of the banana water mass $\left(\mathrm{m}_{\mathrm{a}}\right)$ and the dry banana mass $\left(\mathrm{m}_{\mathrm{s}}\right)$, as follows:

$$
\mathrm{M}=\mathrm{m}_{\mathrm{a}} / \mathrm{m}_{\mathrm{s}}
$$


The dimensionless moisture content of each sample $\left(\mathrm{M}^{*}\right)$ and at each measurement time was calculated based on the value of the moisture content $(\mathrm{M})$, the initial moisture content $\left(\mathrm{M}_{\mathrm{o}}\right)$, and the equilibrium moisture content, $\left(\mathrm{M}_{\mathrm{e}}\right)$ on a dry basis, as follows:

$$
\mathrm{M}^{*}=\left(\mathrm{M}-\mathrm{M}_{\mathrm{e}}\right) /\left(\mathrm{M}_{\mathrm{o}}-\mathrm{M}_{\mathrm{e}}\right) .
$$

The calculation of the dimensionless temperature of each sample $\left(\theta^{*}\right)$ in each measurement time was made based on the banana's surface temperature $(\theta)$, the initial temperature $\left(\theta_{0}\right)$, and the equilibrium temperature $\left(\theta_{\mathrm{e}}\right)$, as follows:

$$
\theta^{*}=\left(\theta-\theta_{\mathrm{e}}\right) /\left(\theta_{\mathrm{o}}-\theta_{\mathrm{e}}\right) .
$$

The calculations of the volume (V) and the surface area of the banana slice (S) in each measurement time were made based on the value of its dimensions, length of the major axis (L), and diameter (D) using the following equations [11,13]:

$$
\begin{gathered}
(\mathrm{V})_{t}=\frac{1}{3} \pi\left(\frac{\mathrm{L}}{2}\right)_{t}\left(\frac{\mathrm{D}}{2}\right)_{t}^{2}, \\
(\mathrm{~S})_{t}=\frac{1}{4} \pi(\mathrm{D})_{t}(\mathrm{~L})_{t}\left\{\frac{(\mathrm{D})_{t}}{(\mathrm{~L})_{t}}+\frac{\arcsin \left[\sqrt{\left[1-\left(\frac{\mathrm{D})_{t}}{(\mathrm{~L})_{t}}\right)^{2}\right]}\right]}{\sqrt{\left[1-\left(\frac{\mathrm{D})_{t}}{(\mathrm{~L})_{t}}\right)^{2}\right]}}\right\},
\end{gathered}
$$

where the subscript $t$ represents the time in that the measurement was done.

\section{Results and Discussion}

Figure 2 illustrates the dimensionless moisture content transient behavior of the banana being dried at temperatures of $40^{\circ} \mathrm{C}, 50^{\circ} \mathrm{C}, 60^{\circ} \mathrm{C}$, and $70^{\circ} \mathrm{C}$. It appears that the average moisture content decreases slowly over time, in the case of drying at low temperature. It can be seen in the graph that the temperature level has a great influence on the drying of the product. Therefore, moisture migration at constant temperature at $70{ }^{\circ} \mathrm{C}$ causes the product to lose moisture faster than at $40{ }^{\circ} \mathrm{C}$, tending to equilibrium moisture content in a shorter time. This phenomenon occurs regardless of the geometric shape of the banana. Note that, due to the moisture content being plotted in dimensionless form, the results are independent from each other of the initial moisture content and balance of the banana in each experimental condition.

Figures 3 and 4 illustrate the dimensional volume variations of the banana over time, for the constant drying temperatures used in the $40{ }^{\circ} \mathrm{C}, 50^{\circ} \mathrm{C}, 60^{\circ} \mathrm{C}$, and $70^{\circ} \mathrm{C}$ oven temperature. It is observed that the volume changes slowly with time for the temperatures of $40^{\circ} \mathrm{C}$ and $50{ }^{\circ} \mathrm{C}$, whereas, for the temperatures of $60^{\circ} \mathrm{C}$ and $70^{\circ} \mathrm{C}$, a much more accentuated volume variation occurs. For example, in 30 min elapsed time, dimensionless average moisture contents of $0.9293,0.8822,0.8520$, and 0.7872 were found, and dimensionless volume $0.966,0.909,0.896$, and 0.792 , for the temperatures $40{ }^{\circ} \mathrm{C}, 50{ }^{\circ} \mathrm{C}$, $60{ }^{\circ} \mathrm{C}$, and $70{ }^{\circ} \mathrm{C}$, respectively. Thus, it is clearly shown that drying and shrinkage rates are found in higher drying-air temperature. 


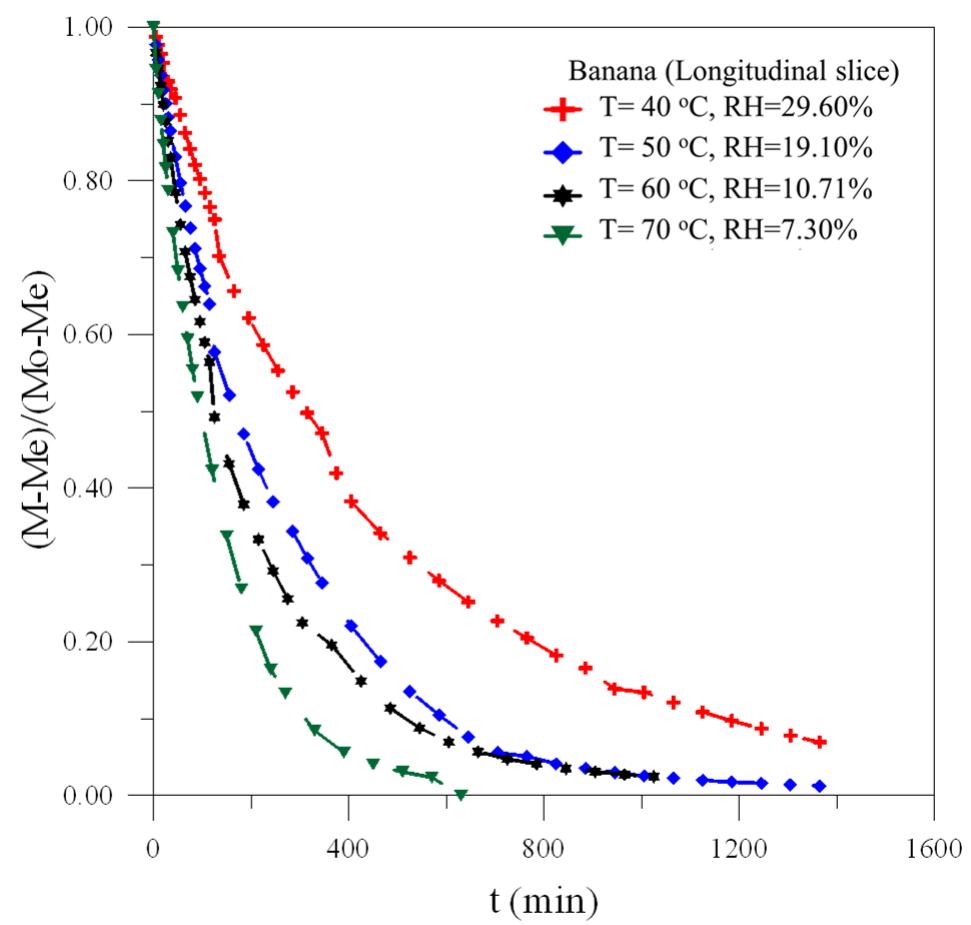

Figure 2. Average dimensionless moisture content of the longitudinal sliced banana as a function of the drying time. T—-temperature; $\mathrm{RH}$-relative humidity.

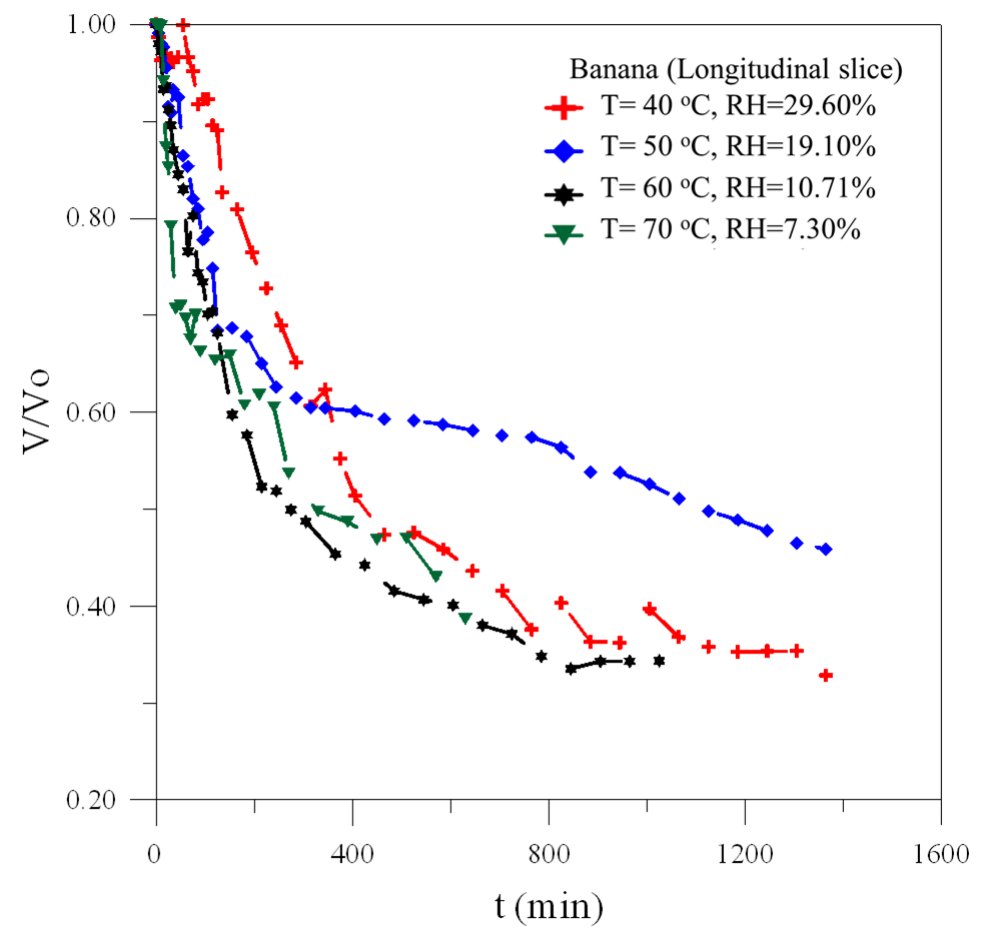

Figure 3. Dimensionless volume of the longitudinal sliced banana as a function of the drying time. 


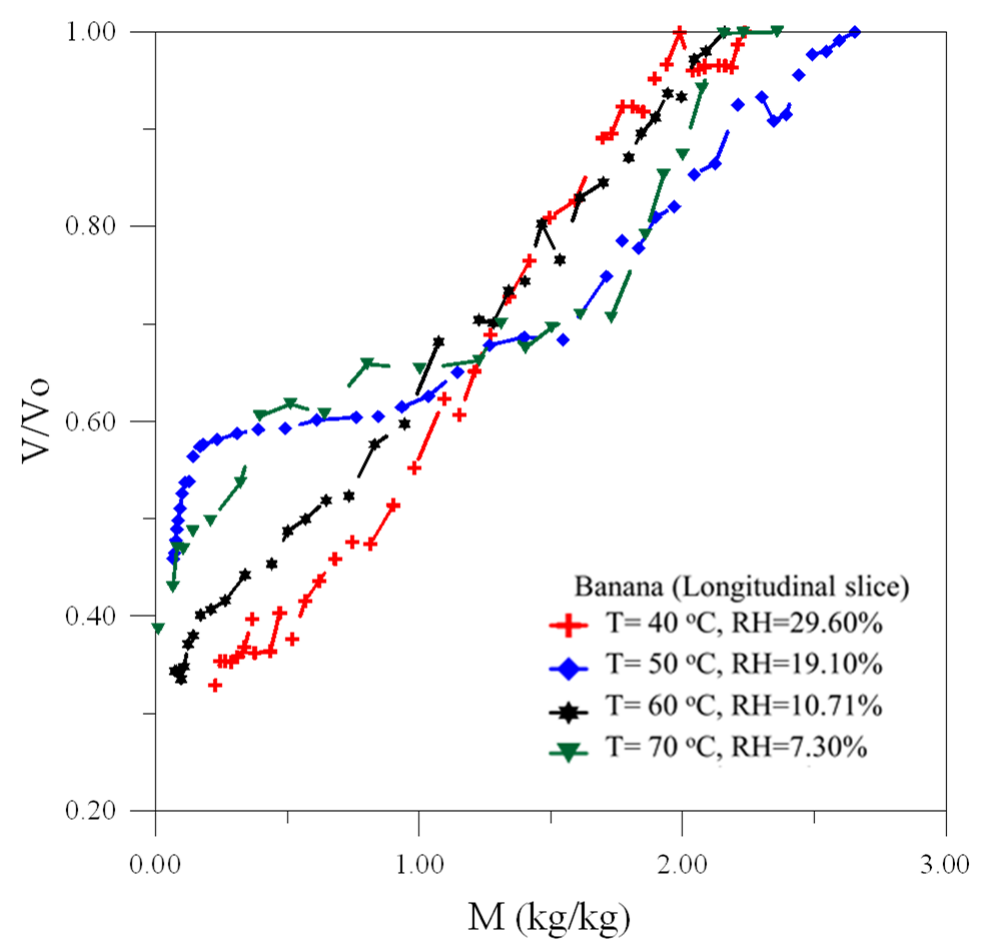

Figure 4. Dimensionless volume of the longitudinal cut banana as a function of moisture content.

It is noted that, for all drying temperatures, at the beginning of the process, there is a higher drying rate. Thus, the dimensions of the fruit changes from a high shrinkage speed until it tends to zero. However, comparing the drying behavior, it is observed that, for the drying temperatures, of $40^{\circ} \mathrm{C}$ and $50^{\circ} \mathrm{C}$, the variation in the volume of the banana occurs more uniformly, due to the fact that the water removal is slower, promoting drying and longer heating. For high temperatures, for example, $60^{\circ} \mathrm{C}$ and $70^{\circ} \mathrm{C}$, at the beginning of the process, there is a great loss of water from the banana, thus causing a sudden reduction in its volume. There is also a linear trend in volume with moisture content, indicating that the reduction in the volume of bananas equals the amount of water removed with the progress of the drying, except for a longer time (>300 $\mathrm{min}$ ), where combined effects of expansion due to heating and contraction due to moisture removal are more important. This effect can be verified by the changes in the behavior of the curves for longer time, which drop smoothly now. Furthermore, there is a different transient behavior of the dimensionless volume for a longer time and drying experiment at $50{ }^{\circ} \mathrm{C}$ as compared with other temperatures: instantaneous higher dimensionless volume. This fact can be explained by the low initial volume, different shrinkage rates on the radial and axial directions, and an increase in the rigidity of the sample during the experiment (not quantitatively verified).

Figures 5 and 6 illustrate the variation of the banana's surface area as a function of drying time and moisture content, respectively, for constant temperatures of $40{ }^{\circ} \mathrm{C}, 50^{\circ} \mathrm{C}, 60^{\circ} \mathrm{C}$, and $70{ }^{\circ} \mathrm{C}$. An analysis of the curves that represents the drying kinetics shows that, at the beginning of the process, there is a large reduction in surface area because, in this drying stage, the product has the highest moisture content and drying rate and, consequently, the greatest water loss. It can also be seen in the graphs that the phenomenon occurs in a much shorter time when using a higher drying air temperature. 


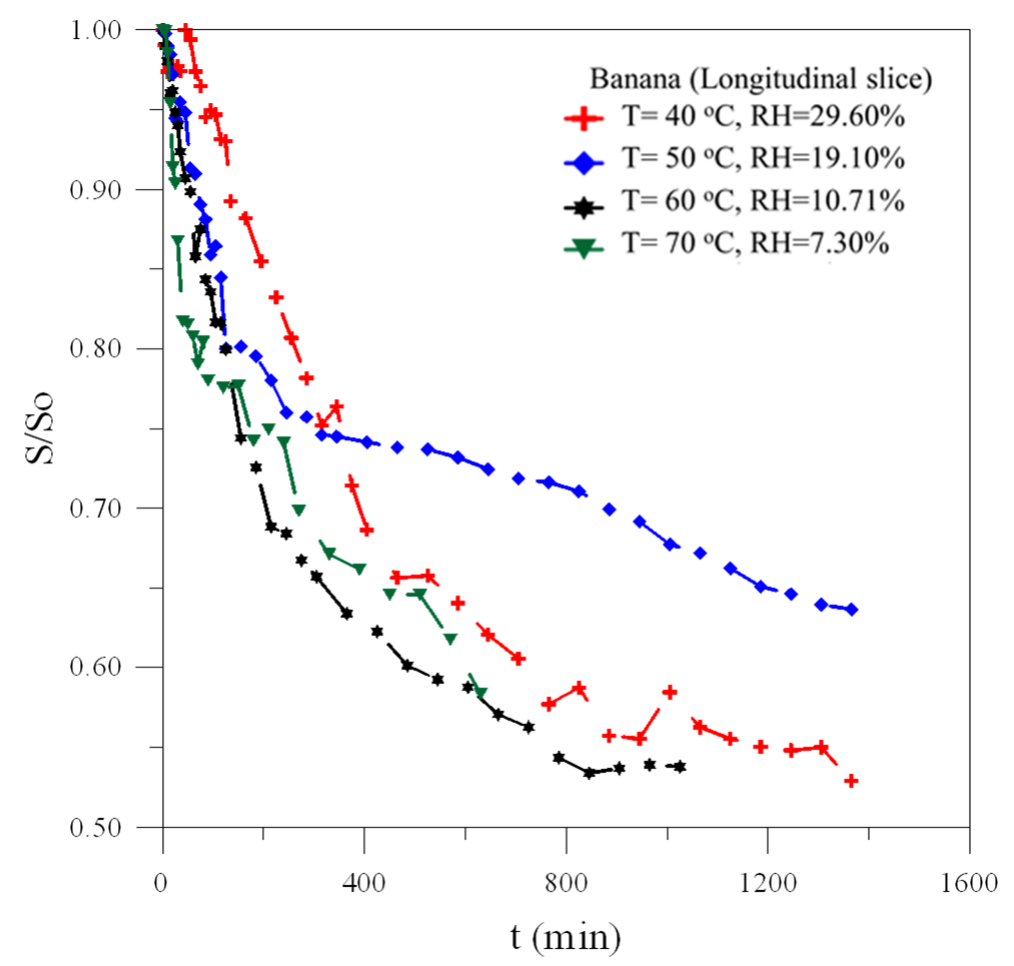

Figure 5. Dimensionless surface area of longitudinal sliced banana as a function of the drying time.

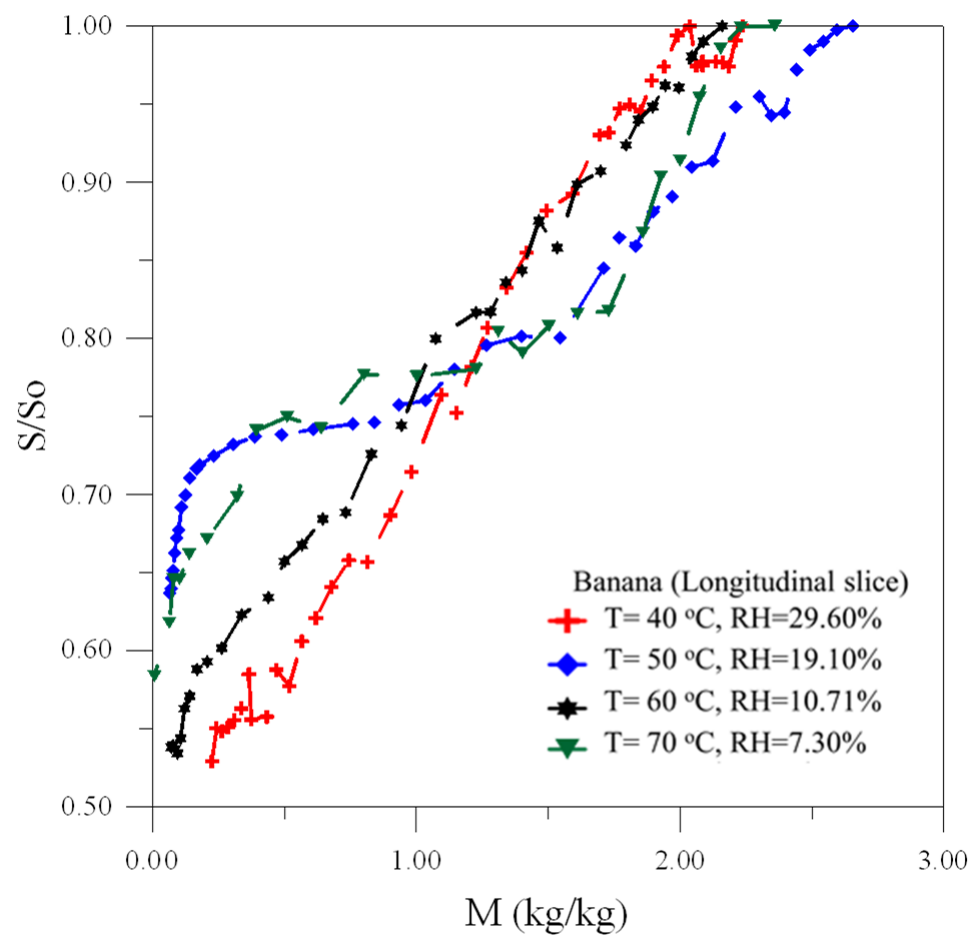

Figure 6. Dimensionless surface area of longitudinal sliced banana as a function of moisture content.

Upon examining Figures 5 and 6, it can also be observed that, for all the drying temperatures evaluated, at the beginning of the process, there is a great loss of moisture and different drying rate, showing that the geometric shape has a great influence on the phenomenon of shrinkage. Thus, the dimensions of the fruit have high variation rates at the beginning of the process and that corresponding dimensional variation rate decreases with the progress of the drying, due to reduction in the loss of moisture of the product. When moisture of the banana approaches zero, shrinkage practically 
does not exist. Furthermore, it is important to emphasize the effect of the relative humidity of the drying air in the process. For a fixed drying air temperature and many other drying parameters (initial moisture content, shape and nature of the product, etc.), the lower the air relative humidity, the greater the drying rate.

Figure 7 illustrates the variations in the surface temperature of the banana over time, for all drying tests performed. It appears that, in a first stage, the rates of temperature variation (heating rates) are more pronounced during the very first few hours of the referred stage, compared to the rates of variation in moisture content (drying rates). Subsequently, in a second stage, approximately after $5 \mathrm{~h}$ of drying, the inversion of trends occurs, with the rates of variation of the moisture content becoming higher. Finally, in a third and final stage, both rates are small, decreasing as the break-even point approaches. This occurs regardless of the geometric shape of the banana and the dying condition (air temperature and relative humidity). Obviously, the air velocity has a major effect in the heating rates [9,33-35], but, herein, drying was done in an air circulation oven where low air velocity was used (almost natural convection of heat).

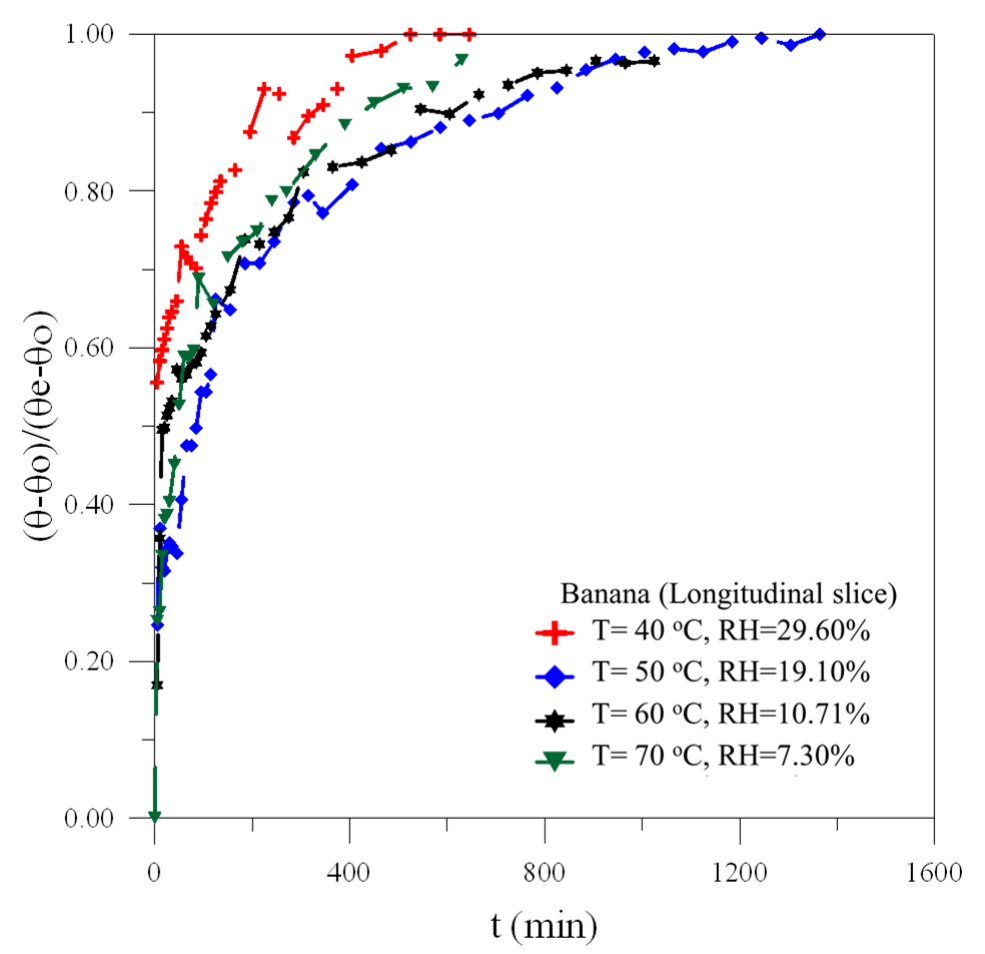

Figure 7. Dimensionless surface temperature of the longitudinal sliced banana as a function of the drying time.

The heat transfer effect can be verified by the convective heat transfer coefficient; however, in practical applications, heat flux and temperature at the surface of a porous material are very difficult to measure without disturbing the heat transfer, especially in the drying process of materials with high moisture content, where simultaneous mass and heat transfer and dimensions variations have occurred.

Previous reports have indicated that drying modifies the shape of the body, decreases the surface area of heat transfer, and increases the superficial roughness of the material. This last characteristic provides an increase of the air flow turbulence level in the boundary layer around the fruit, increasing energy transfer between air and material. Thus, additional complications in the measurement of the heat transfer coefficient are evident [13,35].

Upon analyzing Figures 2 and 7, it can be said that the drying of bananas occurs at a falling rate period, in agreement with results reported in the literature [26,36-40]. For a better understanding, throughout the period of a constant drying rate, the temperature of the product remains constant, 
especially in the initial drying periods (corresponding to the first stage in this study), where water loss is more pronounced. However, this effect was not verified in the experiments carried out in this research (see Figure 7). Taking the transient curves of the surface temperature into consideration, we can see that temperature increases along the entire process. Furthermore, it appears that, for lower temperatures, the curves are smoother, implying a tendency for the thermal diffusivity to be lower for a lower temperature. In this sense, the thermal diffusivity must also be influenced by local temperatures within the solid and moisture content too. There may also be an increase in the convective heat transfer coefficient, or even a combination of an increase in both coefficients [13,35].

Tables 3 and 4 show the dimensional relationships of length, surface area, and volume, for each drying test, as well as the total drying time of each experiment.

Table 3. Dimensional data of the longitudinal sliced banana during drying.

\begin{tabular}{|c|c|c|c|c|c|c|c|c|}
\hline \multirow{2}{*}{$\mathrm{T}\left({ }^{\circ} \mathrm{C}\right)$} & \multicolumn{4}{|c|}{ Start } & \multicolumn{4}{|c|}{ Final } \\
\hline & $\mathrm{D}(\mathrm{mm})$ & $\mathrm{L}(\mathrm{mm})$ & $\mathrm{V}\left(\mathrm{mm}^{3}\right)$ & $\mathrm{S}\left(\mathrm{mm}^{2}\right)$ & $\mathrm{D}(\mathrm{mm})$ & $\mathrm{L}(\mathrm{mm})$ & $\mathrm{V}\left(\mathrm{mm}^{3}\right)$ & $\mathrm{S}\left(\mathrm{mm}^{2}\right)$ \\
\hline $40.0 \pm 0.5$ & $25.34 \pm 0.11$ & $119.04 \pm 0.48$ & 20011.26 & 3792.91 & $15.60 \pm 0.21$ & $103.18 \pm 0.41$ & 6573.75 & 2005.90 \\
\hline $50.0 \pm 0.8$ & $23.43 \pm 0.23$ & $98.87 \pm 0.63$ & 14209.45 & 2924.78 & $16.75 \pm 0.17$ & $88.73 \pm 0.55$ & 6517.31 & 1861.74 \\
\hline $60.0 \pm 1.1$ & $27.20 \pm 0.31$ & $117.96 \pm 0.47$ & 22847.62 & 4046.45 & $17.20 \pm 0.41$ & $101.30 \pm 0.62$ & 7845.75 & 2176.65 \\
\hline $70.0 \pm 0.9$ & $21.62 \pm 0.17$ & $95.55 \pm 0.64$ & 11692.58 & 2603.36 & $14.19 \pm 0.23$ & $85.74 \pm 0.58$ & 4519.77 & 1519.02 \\
\hline
\end{tabular}

Table 4. Relative shrinkage data longitudinal sliced banana during drying.

\begin{tabular}{cccccccc}
\hline $\mathbf{T}\left({ }^{\circ} \mathbf{C}\right)$ & $\mathbf{t}(\mathbf{m i n})$ & $\frac{\mathbf{D}_{\mathbf{f}}}{\mathbf{D}_{\mathbf{o}}}$ & $\frac{\mathbf{L}_{\mathbf{f}}}{\mathbf{L}_{\mathbf{o}}}$ & $\frac{\mathbf{S}_{\mathbf{f}}}{\mathbf{S}_{\mathbf{o}}}$ & $\frac{\mathbf{V}_{\mathbf{f}}}{\mathbf{V}_{\mathbf{o}}}$ & $\mathbf{M}_{\mathbf{o}}$ (w.b.) & $\frac{\mathbf{S}_{\mathbf{o}}}{\mathbf{V}_{\mathbf{o}}}$ \\
\hline $40.0 \pm 0.5$ & 1365 & 0.6156 & 0.8667 & 0.5288 & 0.3285 & 0.6910 & 0.1895 \\
$50.0 \pm 0.8$ & 1365 & 0.7149 & 0.8974 & 0.6365 & 0.4587 & 0.7264 & 0.2058 \\
$60.0 \pm 1.1$ & 1025 & 0.6323 & 0.8587 & 0.5379 & 0.3434 & 0.6835 & 0.1771 \\
$70.0 \pm 0.9$ & 630 & 0.6563 & 0.8973 & 0.5835 & 0.3865 & 0.7023 & 0.2226 \\
\hline
\end{tabular}

By cross-checking Tables 2 and 3 , it can be seen that the banana volume varied $\left(1-\mathrm{V}_{\mathrm{f}} / \mathrm{V}_{\mathrm{o}}\right)$ from $67.15 \%, 54.13 \%, 65.66 \%$, and $61.35 \%$, for temperatures of $40{ }^{\circ} \mathrm{C}, 50{ }^{\circ} \mathrm{C}, 60{ }^{\circ} \mathrm{C}$, and $70{ }^{\circ} \mathrm{C}$, respectively. The smaller dimensions of the banana had a greater linear retraction. It is also observed that there is a small difference between the percentage of variation in the volume of the banana and the complement of the initial moisture content on a wet basis. This is due to small errors in measurement and use of the equipment at the time of reading, perhaps, even by the increase in the rigidity of the banana during drying. These small errors can be attributed to precise measurement locations, which can be different by $1 \mathrm{~mm}$ or $2 \mathrm{~mm}$ easily, in each moment of drying, and local deformation in the fruit provoked by successive measurements along the process. However, there is a trend of linearity between the volume and the moisture content of the solid during the process.

It is also observed that the volumetric variation has a slight tendency to increase with the temperature rise, which is expected since moisture removal has increased with increasing air temperature. Similar behavior occurs with the variation of the surface area, as well as with the dimensions of the banana. This behavior was verified for all drying conditions used in the experiments.

For longitudinally cut banana drying, the drying time at $70{ }^{\circ} \mathrm{C}$ is $63 \%$ less than that at $60{ }^{\circ} \mathrm{C}$, $117 \%$ less compared to $50^{\circ} \mathrm{C}$ and $117 \%$ less than $40^{\circ} \mathrm{C}$. The drying time decreased around $12.3 \mathrm{~h}$ with an increase from $40^{\circ} \mathrm{C}$ to $70^{\circ} \mathrm{C}$ in the drying air temperature. However, it is important to notice that the final moisture content of the banana at $40^{\circ} \mathrm{C}$ is higher than that at $50{ }^{\circ} \mathrm{C}$.

The ratio between the final and initial diameters $\left(D_{f} / D_{o}\right)$ was less than the banana length ratio $\left(\mathrm{L}_{\mathrm{f}} / \mathrm{L}_{\mathrm{o}}\right)$ for all studied cases, as reported in Table 3. This implies that the moisture in the radial direction diffuses more quickly than in the axial direction due to the geometric effect. Thus, it is expected that the diffusion coefficient in the radial direction decreases more than in the axial direction, characterizing an inhomogeneous shrinkage. 
Figure 8 shows the banana slices at different moments of drying at air temperature $60^{\circ} \mathrm{C}$. From the analysis of these figures, we can notice that the surface hardening (increase in the rigidity, mainly due to sugar caramelization), shape, and dimension variations, and loss of color were verified in the fruit at the end of drying. The loss of water and volatiles, which occurs during drying, are responsible to the greater structural variation in the materials that lead to different sensory and texture characteristics of the fresh product [27], mainly in thermo-sensitive materials contained in fruits and vegetables.

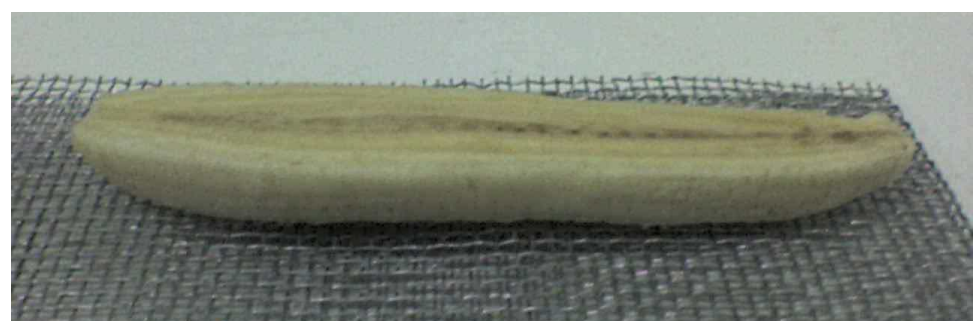

$$
t=0 \mathrm{~min}
$$

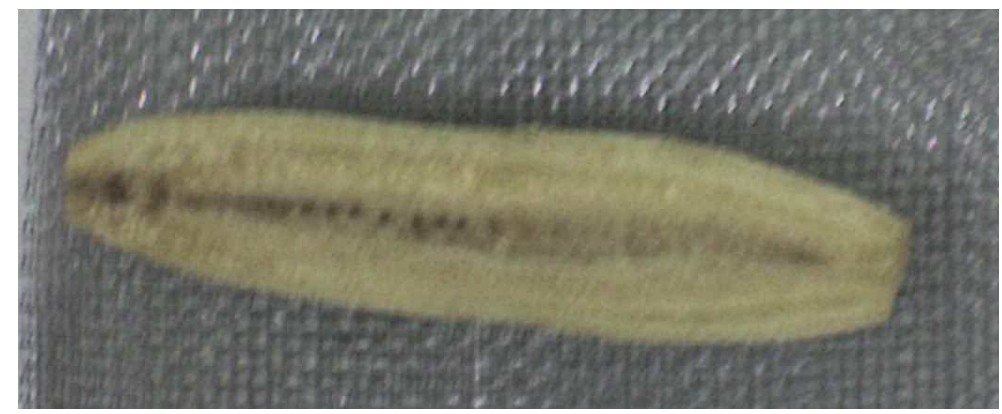

$$
t=37 \mathrm{~min}
$$

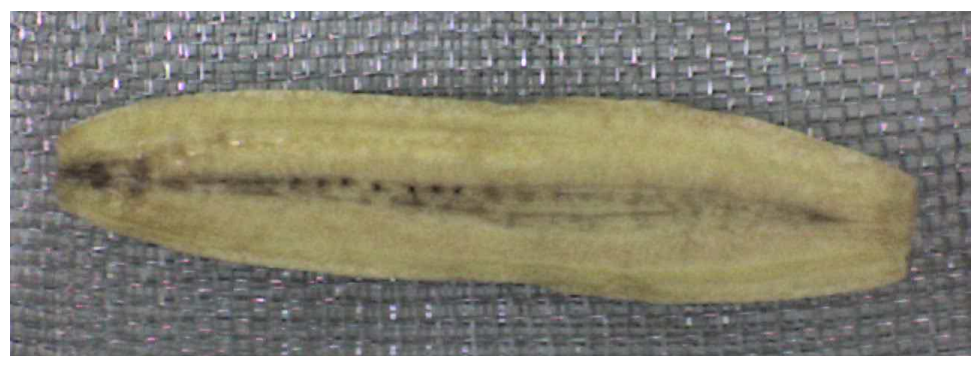

$t=1 \mathrm{~h} 57 \mathrm{~min}$

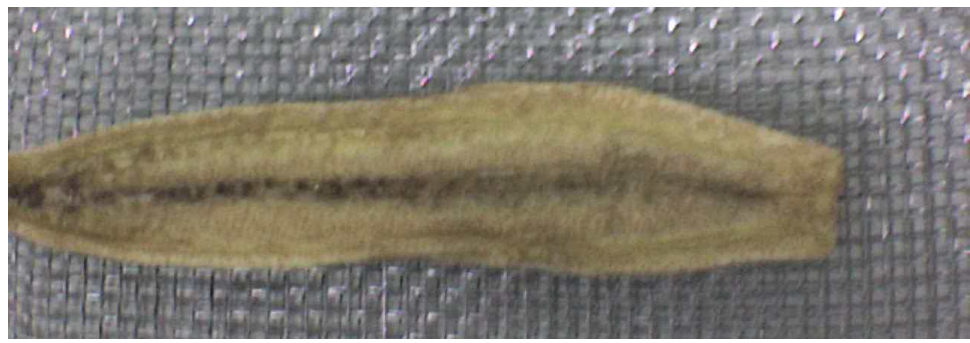

$$
t=5 \mathrm{~h} 59 \mathrm{~min}
$$

Figure 8. Banana slices at different moments of drying $\left(T=60^{\circ} \mathrm{C}\right)$.

As a final comment, from an industry point of view, different related topics to drying of fruits play important roles, such as dryer selection, product quality, energy savings, energy sources, 
energy efficiency, energy recovery, operating safety, and environmental impact, and some questions need explanation-for example: Drying provokes irreversible effect in the product? How can this be done efficiently in terms of time, energy cost, and investment and product quality?

Under the consumers' point of view, the quality of dried fruits must obey many criteria related mainly to appearance, aroma, texture, convenience of use, rapidity of rehydration, and of dissolution, ease of package opening, constancy of apparent density, keeping qualities, and composition.

Drying is a highly energy-consuming process, one of the major sources of pollutant emissions, and one dehydration technique that strongly affects product quality under different aspects such as color, flavor, appearance, aroma, losses of nutrients and vitamins, and many other physical, chemical, structural, and nutritional quality parameters. Thus, the following factors of dried fruits can be cited: quality of raw material, pretreatments, drying conditions, packaging, and storage conditions.

Based on the comments above, the real contribution of this paper in terms of process time, product quality and energy consumption is clear. Since total cost and product quality are competing parameters, the idea is to help specialists based on scientific knowledge necessary to improve the drying process and dryer efficiency.

\section{Conclusions}

Dried bananas play an important role in the human diet throughout the world. In this paper, the drying process of banana slices was analyzed with one drying mechanism (heat convection in air circulation ovens). The effect of drying conditions on the moisture removal and heating of banana longitudinal sliced has shown that the process occurred in the falling drying rate period, and higher temperature and lower relative humidity provoked higher drying, heating, and shrinkage rates in the fruit. Increasing air temperature significantly reduced the drying time of the longitudinal sliced banana. The study proved that drying under controlled conditions has a greater potential to increase shelf-life and guarantee high quality in bananas with high moisture content. Based on the obtained results in terms of process time (energy saving, energy cost and productivity), and qualitative analysis of the fruit after drying, the authors suggest an air temperature of $60{ }^{\circ} \mathrm{C}$ and air relative humidity of $11 \%$ as the more appropriate conditions for drying of bananas longitudinally sliced in the oven.

Author Contributions: Conceptualization, R.P.F., W.P.S., L.P.L.S., G.L.O.N., I.B.S., J.E.F.C., J.J.S.N. and A.G.B.L.; Data curation, I.B.S.; Formal analysis, W.P.S., J.E.F.C., J.J.S.N. and A.G.B.L.; Funding acquisition, I.B.S.; Investigation, W.P.S., L.P.L.S., I.B.S. and A.G.B.L.; Methodology, R.P.F., R.S.G., L.P.L.S., G.L.O.N., J.E.F.C., J.J.S.N. and A.G.B.L.; Project administration, G.L.O.N.; Software, R.P.F., R.S.G., W.P.S., J.E.F.C., and J.J.S.N.; Supervision, R.S.G., W.P.S., G.L.O.N., J.E.F.C., J.J.S.N. and A.G.B.L.; Validation, R.P.F., W.P.S., L.P.L.S. and A.G.B.L.; Visualization, L.P.L.S.; Writing—original draft, R.P.F., W.P.S., I.B.S., J.E.F.C., J.J.S.N and A.G.B.L.; Writing-review and editing, R.P.F., R.S.G., W.P.S., G.L.O.N., I.B.S. and A.G.B.L. All authors have read and agreed to the published version of the manuscript.

Funding: This research was funded by CNPq, CAPES, FINEP (Brazilian research agencies) and the State University of Paraiba (Brazil).

Acknowledgments: The authors are grateful to the State University of Paraiba (Brazil) for the financial support and the references cited in the manuscript.

Conflicts of Interest: The authors declare no conflict of interest.

\section{References}

1. Sidhu, J.S.; Zafar, T.A. Bioactive compounds in banana fruits and their health benefits. Food Qual. Saf. 2018, 2, 183-188. [CrossRef]

2. Melo, C.C.R. Post-Harvest Losses of 'Prata-Anã' Banana on the Farm and Retail Market: A Case Study. Ph.D. Thesis, Federal University of Viçosa, Viçosa, Brazil, 2013.

3. Farias, R.P.; Oliveira, V.A.B.; Brandão, V.A.A.; Silva, W.P.; Lima, A.G.B.; Nascimento, J.J.S. Drying of banana slices: Lumped model application and experiments. Def. Diff. Forum 2019, 391, 42-47. [CrossRef] 
4. $\quad$ Farias, R.P.; Santos, R.S.; Gomes, R.S.; Silva, W.P.; Barbalho, G.H.A.; Cavalcante, A.M.M.; Lima, A.G.B. Drying of banana slices in cylindrical shape: Theoretical and experimental investigations. Def. Diff. Forum 2020, 399, 183-189. [CrossRef]

5. Yang, H.; Sombatngamwilai, T.; Yu, W.-Y.; Kuo, M.-I. Drying applications during value-added sustainable processing for selected mass-produced food coproducts. Processes 2020, 8, 307. [CrossRef]

6. Wakjira, M.; Adugna, D.; Yadessa, G. determining slice thickness of banana (Musa spp.) for enclosed solar drying using solar cabinet dryer under ethiopian condition. Am. J. Food Technol. 2011, 6, 568-580. [CrossRef]

7. Omolola, A.O.; Jideani, A.I.O.; Kapila, P.F. Drying kinetics of banana (Musa spp.). Interciencia 2015, 40, 374-380.

8. Ahmad, B.A.; Zakariyya, U.A.; Abubakar, M.; Sani, M.M.; Ahmad, M.A. Pharmacological activities of banana. In Banana Nutrition-Function and Processing Kinetics, 1st ed.; Jideani, A.I.O., Anyasi, T.A., Eds.; IntechOpen: London, UK, 2019; Volume 1, Available online: https://www.intechopen.com/books/ banana-nutrition-function-and-processing-kinetics/pharmacological-activities-of-banana (accessed on 22 April 2020). [CrossRef]

9. Wang, N.; Brennan, J.G. Change in structure, density and porosity of potato during dehydration. J. Food Eng. 1995, 24, 61-76. [CrossRef]

10. Bialobrewski, I.; Magdalena, Z.; Mujumdar, A.S.; Marek, M. Heat and mass transfer during drying of a bed of shrinking particles-Simulation for carrot cubes dried in a spot-fluidized-bed drier. Int. J. Heat Mass Transf. 2008, 51, 4704-4716. [CrossRef]

11. Lima, A.G.B.; Queiroz, M.R.; Nebra, S.A. Simultaneous moisture transport and shrinkage during drying of solids with ellipsoidal configuration. Chem. Eng. J. 2002, 86, 85-93. [CrossRef]

12. Ganesapillai, M.; Regupathi, I.; Murugesan, T. Modeling of thin layer drying of banana (Nendran Spp) under microwave, convective and combined microwave-convective processes. Chem. Prod. Proc. Model. 2011, 6. [CrossRef]

13. Lima, A.G.B.; Farias Neto, S.R.; Silva, W.P. Heat and mass transfer in porous materials with complex geometry: Fundamentals and applications. In Heat and Mass Transfer in Porous Media, 1st ed.; Delgado, J.M.P.Q., Ed.; Springer-Verlag: Heidelberg, Germany, 2011; Volume 13, pp. 161-185.

14. Obiageli, O.A.; Ohia, G.U.; Pauline, I.A.; Helen, O.N. Glycoside, moisture and dry matter compositions of fruits of three musa species at three stages of development. IOSR J. Pharm. Biol. Sci. 2016, 11, 60-67. [CrossRef]

15. Netshiheni, R.K.; Omolola, A.O.; Anyasi, T.A.; Jideani, A.I.O. Banana bioactives: Absorption, utilisation and health benefits. In Banana Nutrition-Function and Processing Kinetics, 1st ed.; Jideani, A.I.O., Anyasi, T.A., Eds.; IntechOpen: London, UK, 2019; Volume 1, p. 83369. Available online: https://www.intechopen.com/books/banana-nutrition-function-and-processing-kinetics/ banana-bioactives-absorption-utilisation-and-health-benefits (accessed on 22 April 2020). [CrossRef]

16. Talla, A.; Puiggali, J.-R.; Jomaa, W.; Jannot, Y. Shrinkage and density evolution during drying of tropical fruits: Application to banana. J. Food Eng. 2004, 64, 103-109. [CrossRef]

17. Prachayawarakorn, S.; Tia, W.; Plyto, N.; Soponronnarit, S. Drying kinetics and quality attributes of low-fat banana slices dried at high temperature. J. Food Eng. 2008, 85, 509-517. [CrossRef]

18. Baini, R.; Langrish, T.A.G. An assessment of the mechanisms for diffusion in the drying of banana. J. Food Eng. 2008, 85, 201-214. [CrossRef]

19. Smitabhindu, R.; Janjai, S.; Chankong, V. Optimization of a solar-assisted for drying banana. Renew. Energy 2008, 33, 1523-1531. [CrossRef]

20. Thuwapanichayanan, R.; Prachayawarakron, S.; Soponronnarit, S. Drying characteristics and quality of banana foam mat. J. Food Eng. 2008, 86, 573-583. [CrossRef]

21. Mariani, V.C.; Lima, A.G.B.; Coelho, L.S. Apparent thermal diffusivity estimation of the banana during drying using inverse method. J. Food Eng. 2008, 85, 569-579. [CrossRef]

22. Azoubel, P.M.; Baima, M.A.M.; Amorim, M.R.; Oliveira, S.S.B. Effect of ultrasound on banana cv Pacovan drying kinetics. J. Food Eng. 2010, 97, 194-198. [CrossRef]

23. Rahman, M.H.; Ahmed, M.W.; Islam, M.N. Drying kinetics and sorption behavior of two varieties banana (Sagor and Sabri) of Bangladesh. SAARC J. Agric. 2018, 16, 181-193. [CrossRef]

24. Souza, L.F.; Andrade, E.T.; Rios, P.A. Determination of volumetric contraction and drying kinetics of the dryed banana. Theor. Appl. Eng. 2019, 3, 20-30. [CrossRef] 
25. Olalekan, A.S.A. Banana drying kinetics. In Banana Nutrition-Function and Processing Kinetics, 1st ed.; Jideani, A.I.O., Anyasi, T.A., Eds.; IntechOpen: London, UK, 2020; Volume 1, Available online: https:/www.intechopen.com/books/banana-nutrition-function-and-processing-kinetics/ banana-drying-kinetics (accessed on 25 April 2020). [CrossRef]

26. Maskan, M. Microwave/air and microwave finish drying of banana. J. Food Eng. 2000, 44, 71-78. [CrossRef]

27. Ramos, I.N.; Brandão, T.R.S.; Silva, C.L.M. Structural changes during air drying of fruits and vegetables. Food Sci. Technol. Int. 2003, 9, 201-206. [CrossRef]

28. Swasdisevi, R.; Devahastin, S.; Sa-Adchom, P.; Soponronnarit, S. Mathematical modeling of combined far-infrared and vacuum drying banana slice. J. Food Eng. 2009, 92, 100-106. [CrossRef]

29. Nguyen, M.H.; Price, W.E. Air-drying of banana: Influence of experimental parameters, slab thickness, banana maturity and harvesting season. J. Food Eng. 2007, 79, 200-207. [CrossRef]

30. Pan, Z.; Shih, C.; Mchugh, T.H.; Hirschberg, E. Study of banana dehydration using sequential infrared radiation heating and freeze-drying. LTW Food Sci. Technol. 2008, 41, 194-195. [CrossRef]

31. Junlakan, W.; Yamsaengsung, R.; Tirawanichakul, S. Effects of vacuum drying on structural changes of banana slices. ASEAN J. Chem. Eng. 2013, 13, 1-10. [CrossRef]

32. Kumar, P.S.; Nambi, E.; Shiva, K.N.; Vaganan, M.M.; Ravi, I.; Jeyabaskaran, K.J.; Uma, S. Thin layer drying kinetics of Banana var. Monthan (ABB): Influence of convective drying on nutritional quality, microstructure, thermal properties, color, and sensory characteristics. J. Food Process. Eng. 2019, 42, 12. [CrossRef]

33. Saravacos, G.D.; Kostaropoulos, A.E. Transport properties in processing of fruits and vegetables. Food Technol. 1995, 49, 99-105.

34. ASHRAE Thermal properties of foods. In ASHRAE Handbook-Fundamentals; American Society of heating, Refrigeration and Air-Conditioning Engineers, Inc.: Atlanta, GA, USA, 1993; pp. 30.1-30.26.

35. Lima, A.G.B.; Queiroz, M.R.; Nebra, S.A. Heat and mass transfer model including shrinkage applied to ellipsoids products: Case study: Drying of bananas. Dev. Chem. Eng. Mineral. Process. 2002, 10, 281-304. [CrossRef]

36. Phoungchandang, S.; Woods, J.L. Moisture diffusion and desorption isotherms for banana. J. Food Sci. 2000, 65, 651-657. [CrossRef]

37. Dandamrongrak, R.; Young, G.; Mason, R. Evaluation of pre-treatments for the dehydration of banana and selection of suitable drying models. J. Food Eng. 2002, 55, 139-146. [CrossRef]

38. Queiroz, M.R.; Nebra, S.A. Theoretical and experimental analysis of the drying kinetics of bananas. J. Food Eng. 2001, 47, 127-132. [CrossRef]

39. Demirel, D.; Turhan, M. Air-drying behavior of cavendish and gros michel banana slices. J. Food Eng. 2003, 59, 1-11. [CrossRef]

40. Karim, A.M.D.; Hawlader, M.N.A. Drying characteristics of banana: Theoretical modeling and experimental validation. J. Food Eng. 2005, 70, 35-45. [CrossRef] 